ISSN 0258-7122 (Print), 2408-8293 (Online)

Bangladesh J. Agril. Res. 42(3): 487-501, September 2017

\title{
EFFECT OF SALT AND WATER STRESS ON GAS EXCHANGE, DRY MATTER PRODUCTION AND K+/Na+ IONS SELECTIVITY IN SOYBEAN
}

\author{
M. S. A. KHAN ${ }^{1}$, M. A. KARIM${ }^{2}$, M. M. HAQUE ${ }^{3}$ \\ A. J. M. S. KARIM ${ }^{4}$ AND M. A. K. MIAN ${ }^{5}$
}

\begin{abstract}
The experiment was conducted in a vinylhouse at the Banghabandhu Sheikh Mujibur Rahman Agricultural University, Bangladesh during January to May, 2012 to evaluate the effect of salt and water stress on gas exchange characters, dry matter production and $\mathrm{K}^{+} / \mathrm{Na}^{+}$ions selectivity in three selected soybean genotypes, namely Galarsum, BD 2331 and BARI Soybean-6. The genotypes were exposed to six treatments viz. (i) control (tap water), (ii) water shortage (irrigation with 70\% depletion of available soil water when leaf began to wilt at 10:00 am), (iii) $50 \mathrm{mM} \mathrm{NaCl}$ irrigation, (iv) $50 \mathrm{mM} \mathrm{NaCl}$ irrigation + water shortage, (v) $75 \mathrm{mM} \mathrm{NaCl}$ irrigation, and (vi) $75 \mathrm{mM} \mathrm{NaCl}$ irrigation + water shortage conditions. The results revealed that $75 \mathrm{mM} \mathrm{NaCl}$ salt + water stress treatment drastically reduced stomatal conductance, photosynthesis and transpiration rate irrespective of soybean genotypes. However, the genotype Galarsum showed minimum transpiritional water loss $\left(1.45 \mathrm{mmol} \mathrm{H}_{2} \mathrm{O} \mathrm{m}^{-2} \mathrm{~s}^{-1}\right)$ and maximum photosynthesis $\left(20.45 \mu \mathrm{mol} \mathrm{CO}_{2} \mathrm{~m}^{-2} \mathrm{~s}^{-1}\right)$ as compared to BD 2331 and BARI Soybean-6 under $75 \mathrm{mM} \mathrm{NaCl}$ salt + water stress condition. Combined salt and water stress caused greater inhibition of shoot growth than either of the two in soybean. The shoot dry weights were decreased to 24.58, 23.00 and $21.57 \%$ of the control in Galarsum, BD 2331 and BARI Soybean-6, respectively at $75 \mathrm{mM} \mathrm{NaCl}$ salt + water stress. The genotype Galarsum accumulated higher amount of $\mathrm{K}^{+}(1.19 \%)$ and lower amount of $\mathrm{Na}^{+}(0.11 \%)$ in leaf tissue under $75 \mathrm{mM} \mathrm{NaCl}$ salt + water stress. Results indicated that the genotype Galarsum was more capable to cope with the high levels of salt under water stress condition than the other two genotypes.
\end{abstract}

Keywords: Soybean; Salt and water stress; Photosynthesis; Respiration; Shoot dry matter; Ion uptake

\section{Introduction}

Soybean (Glycine max L.) is a minor crop in Bangladesh though it is considered as one of the most nutritious crops in the world (Yaklich et al., 2002). Currently, it is gaining popularity in the country for its increasing demand as an ingredient of animal feed as well as for the consciousness of its high nutrition value as human food (Karim et al., 2012).

${ }^{1}$ Agronomy Division, Bangladesh Agricultural Research Institute (BARI), Gazipur,

${ }^{2-5}$ Banghabandhu Sheikh Mujibur Rahman Agricultural University (BSMRAU), Gazipur, Bangladesh. 
Consequently its area is increasing especially in the marginal lands called charland (land formed due to accretion of silt on riverbed) and coastal land of southern part of Bangladesh (Islam and Rahman, 2011). Since 1973, the salinity of coastal land has been increased to $27 \%$ and the area exceeded one million ha at various levels. More areas are under threat of salinization due to the combined effects of sea level rise, increased tidal effect, introduction of brackish water for shrimp cultivation, continuous reduction of river flow particularly during dry period, capillary upward movement of soluble salts due to presence of high saline ground water table at shallower depth and faulty management of sluice gates in the south and south-western part of Bangladesh (Karim et al., 2014). This causes lower cropping intensity and it is imperative to increase cropping intensity and productivity of the saline belt of Bangladesh. Since soybean is considered as a moderately salt tolerant crop (Mannan et al., 2012), it may be a potential candidate crop for exploiting the relatively low saline areas after rainy season rice (aman) harvest in the southern Bangladesh. Besides, salt and water stress prevails at the same time in dry seasons, which very often adds extra harm on plant growth (Karim et al., 1993). The adverse effects of both salt and water stress are primarily due to the restriction of water uptake by the roots (Karim et al., 1993), which decreased relative water content (Orcutt and Nilsen, 2000). Therefore, plants are unable to maintain metabolic activities or turgidity for normal growth because of the low osmotic potential in soil. At the same time, plants absorb damaging amounts of $\mathrm{Na}^{+}$and $\mathrm{Cl}^{-}$(Blum, 1988; Greenway and Munns, 1980; Karim et al., 1992). $\mathrm{Na}^{+}$is the primary cause of ion specific damage, resulting due to a range of disorders in enzyme activation and protein synthesis (Tester and Davenport, 2003). In addition, $\mathrm{Na}^{+}$acts as a competitor of $\mathrm{K}^{+}$uptake in plant (Watad et al., 1991; Schroeder et al., 1994). In salt-adapted cells, no inhibition of $\mathrm{K}^{+}$uptake by $\mathrm{NaCl}$ was observed indicating a higher $\mathrm{K}^{+} / \mathrm{Na}^{+}$selectivity at the plasma membrane (Watad et al., 1991). Therefore, exclusion of $\mathrm{Na}^{+}$at root level and maintenance of high $\mathrm{K}^{+}$at shoot level are vital for the plants to grow under saline conditions (Munns et al., 2000; Tester and Davenport, 2003). Leaf photosynthetic capacity is suggested to be a key parameter determining crop yield (Jiang et al., 2002; Zhang et al., 2007). The rate of photosynthetic $\mathrm{CO}_{2}$ assimilation is generally reduced by salinity and drought (Lee et al., 2004; Purwanto, 2003). Salt and water stress have various effects on physiological processes in plants. Extent of physiological changes in plants growing under salt and water deficit conditions is considered as an effective tool for identifying stress tolerant soybean for saline belt of Bangladesh. Therefore, this experiment was undertaken to analyze the physiological response in relation to gas exchange, dry matter distribution and mineral ions accumulation pattern in three high yielding soybean genotypes exposed to salt and water stress conditions.

\section{Materials and Method}

A pot experiment was carried out in a vinylhouse of the Department of Agronomy at Banghabandhu Sheikh Mujibur Rahman Agricultural University 
(BSMRAU), Gazipur, Bangladesh during January to May, 2012. The location of the experimental site is situated at about $24^{\circ} 23^{\prime}$ north latitude, $90^{\circ} 08^{\prime}$ east longitude and an altitude of $8.4 \mathrm{~m}$. Three genotypes of soybean (Galarsum, BD 2331 and BARI Soybean-6) were grown in six environmental conditions of salinity and water stress. The environmental conditions were (i) control, (ii) water shortage (irrigation with $70 \%$ depletion of available soil water when leaf began to wilt at 10:00 am), (iii) $50 \mathrm{mM} \mathrm{NaCl}$ irrigation, (iv) $50 \mathrm{mM} \mathrm{NaCl}$ irrigation + Water shortage, (v) $75 \mathrm{mM} \mathrm{NaCl}$ irrigation, and (vi) $75 \mathrm{mM} \mathrm{NaCl}$ irrigation+ Water shortage. The experiment was arranged in a two factor completely randomized design (CRD) with four replications. The genotypes were selected based on their better performance in previous study (Khan et al., 2014). Treatments were imposed after three weeks of seedling emergence. In salt water irrigation and water shortage treatments, initially all pots were irrigated with salt water for a week then water shortage, and thereafter salt water irrigations were applied. The control plants were irrigated with tap water only at field capacity of the soil. Treatments were applied up to harvest. The soils of each pot contained $12 \mathrm{~kg}$ air dried sandy loam soil fertilized uniformly with $0.30 \mathrm{~g}$ of urea, $0.90 \mathrm{~g}$ of triple super phosphate, $0.60 \mathrm{~g}$ of muriate of potash and $0.60 \mathrm{~g}$ of gypsum before sowing. Five seeds were sown in the soil medium on 20 January, 2012. After the emergence and establishment, two uniform healthy seedlings per pot were allowed to grow for three weeks in the same environment. Admire 200SL @ 1 $\mathrm{ml} /$ liter of water was sprayed at 10 and 25 days after emergence to control Jassids and white flies. Ripcord 10 EC @ 1 ml/liter of water was sprayed at 45 and 55 days after emergence to control leaf roller and pod borer. Gas exchange measurements like photosynthetic rate $(\mathrm{Pn})$, stomatal conductance, total conductance to $\mathrm{CO}_{2}$ and transpiration (E) were measured at 49 days after emergence (after 4 weeks of treatments imposition) by Li-COR 6400 portable photosynthetic system (Li-COR, Lincoln, NE, United States). All the measurements were taken in a bright day between 11:00 and 13:00 h when photosynthetically active radiation (PAR) was between 1100 and $1200 \mu \mathrm{mol} \mathrm{m}^{-}$ ${ }^{2} \mathrm{~s}^{-1}$. Photosynthetic water use efficiency (PWUE) was calculated as the ratio between Pn and E. Plants were harvested at 63 days after emergence and different parts of the plant were separated and then oven dried at $70{ }^{\circ} \mathrm{C}$ for 4 days to measure the dry weight of the shoot. Dried leaf samples were used to measure the $\mathrm{Na}^{+}$and $\mathrm{K}^{+}$ions concentrations of the respective treatments. Collected data were analyzed using STAR (Statistical Tool for Agricultural Research) program and the treatments means were compared by using Tukeys's Honestly Significant Difference (HSD) Test at $\mathrm{P} \leq 0.05$.

\section{Results and Discussion}

Stomatal conductance to $\mathrm{H}_{2} \mathrm{O}$ : Stomatal conductance to $\mathrm{H}_{2} \mathrm{O}$ of soybean genotypes was significantly affected by salinity and water stress treatments (Fig .1). Under water stress treatment, BARI Soybean-6 gave significantly the highest conductance $\left(0.32 \mathrm{~mol} \mathrm{H}_{2} \mathrm{O} \mathrm{m}^{-2} \mathrm{~s}^{-1}\right)$ to water and BD $2331\left(0.14 \mathrm{~mol} \mathrm{H}_{2} \mathrm{O} \mathrm{m}^{-2} \mathrm{~s}^{-1}\right)$ 
showed the least, which was identical to the response of Galarsum. The results however, varied under salt stress and, combined salt and water stress conditions. As compared to the salt stress stomatal conductance to $\mathrm{H}_{2} \mathrm{O}$ was highly affected by the combined salt + water stress at both the salinity levels $(50$ and $75 \mathrm{mM}$ $\mathrm{NaCl}$ ). However, significantly the highest conductance of 0.21 and $0.16 \mathrm{~mol} \mathrm{H}_{2} \mathrm{O}$ $\mathrm{m}^{-2} \mathrm{~s}^{-1}$ was recorded in Galarsum at 50 and $75 \mathrm{mM} \mathrm{NaCl}$ salt stress, respectively. BD 2331 had the identical response to the conductance at the same treatments. The lowest conductance of 0.13 and $0.12 \mathrm{~mol} \mathrm{H}_{2} \mathrm{O} \mathrm{m}^{-2} \mathrm{~s}^{-1}$ was obtained by BARI Soybean-6 at 50 and $75 \mathrm{mM} \mathrm{NaCl}$ salt stress, respectively. Under $75 \mathrm{mM} \mathrm{NaCl}$ salt + water stress condition Galarsum showed significantly the highest conductance $\left(0.04 \mathrm{~mol} \mathrm{H}_{2} \mathrm{O} \mathrm{m} \mathrm{m}^{-2}\right.$ ), while both BD 2331 and BARI Soybean-6 genotypes had the least $\left(0.03 \mathrm{~mol} \mathrm{H}_{2} \mathrm{O} \mathrm{m} \mathrm{m}^{-2} \mathrm{~s}^{-1}\right)$. Genotypic variation of soybean was observed in respect of stomatal conductance to water. These findings are in conformity with that of Kusvuran (2012) who reported that stomatal conductance of the melon genotypes decreased under salt and drought stress and it was slower in the resistant genotypes than sensitive ones.

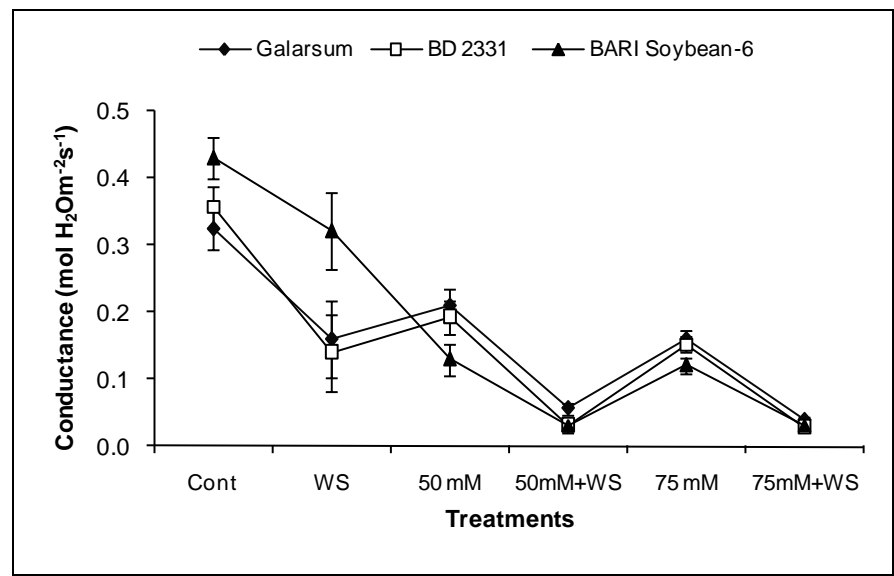

Fig. 1. Stomatal conductance to water as affected by salinity and water stress treatment. Bar represents mean \pm S.E. of the genotypes at the same level of treatment.

Here, Cont $=$ Control, $\mathrm{WS}=$ Water stress and $\mathrm{mM}=\mathrm{NaCl}$ concentration in $\mathrm{mM}$.

Total conductance to $\mathrm{CO}_{2}$ : Total conductance to $\mathrm{CO}_{2}$ of soybean genotypes was distinctly reduced under water stress, salt stress and, combined salt + water stress conditions as compared to control (Fig. 2). Conductance to $\mathrm{CO}_{2}$ was significantly high in BARI Soybean-6 $\left(0.29 \mathrm{~mol} \mathrm{CO}_{2} \mathrm{~m}^{-2} \mathrm{~s}^{-1}\right)$ under only water stress condition, though drastically reduced in Galarsum and BD 2331. The genotype BD 2331 showed the least conductance $\left(0.14 \mathrm{~mol} \mathrm{CO}_{2} \mathrm{~m}^{-2} \mathrm{~s}^{-1}\right)$ under water stress. The total conductance reduced lesser extent in the salt stress conditions as compared to the combined salt + water stress conditions at both the salinity levels $(50$ and $75 \mathrm{mM}$ $\mathrm{NaCl}$ ). At the lower level of salt stress conditions Galarsum showed significantly the highest conductance $\left(0.20 \mathrm{~mol} \mathrm{CO}_{2} \mathrm{~m}^{-2} \mathrm{~s}^{-1}\right)$, which was identical with that of 
BD 2331. BARI Soybean-6 showed the least conductance $\left(0.12 \mathrm{~mol} \mathrm{CO}_{2} \mathrm{~m}^{-2} \mathrm{~s}^{-1}\right)$. At the highest level of salt stress $(75 \mathrm{mM} \mathrm{NaCl})$, Galarsum and BD 2331 showed the highest conductance $\left(0.12 \mathrm{~mol} \mathrm{CO} \mathrm{Cm}^{-2} \mathrm{~s}^{-1}\right)$ and BARI Soybean-6 the least $\left(0.10 \mathrm{~mol} \mathrm{CO}_{2} \mathrm{~m}^{-2} \mathrm{~s}^{-1}\right)$.

Under the low level of salinity + water stress condition genotype Galarsum showed the highest conductance $\left(0.05 \mathrm{~mol} \mathrm{CO}_{2} \mathrm{~m}^{-2} \mathrm{~s}^{-1}\right)$, which was identical with that of BD 2331 and BARI Soybean-6. Under the high level of salinity + water stress conditions all genotypes had similar conductance to $\mathrm{CO}_{2}$. Total conductance to $\mathrm{CO}_{2}$ through stomata and mesophyll decreased due to low water availability under salt and water stress. Turner et al. (1998) reported that stomatal conductance decreased as the osmotic potential decreased in sorghum and sunflower. Similar results were also found by Dadkhah (2010) in sugar beet.

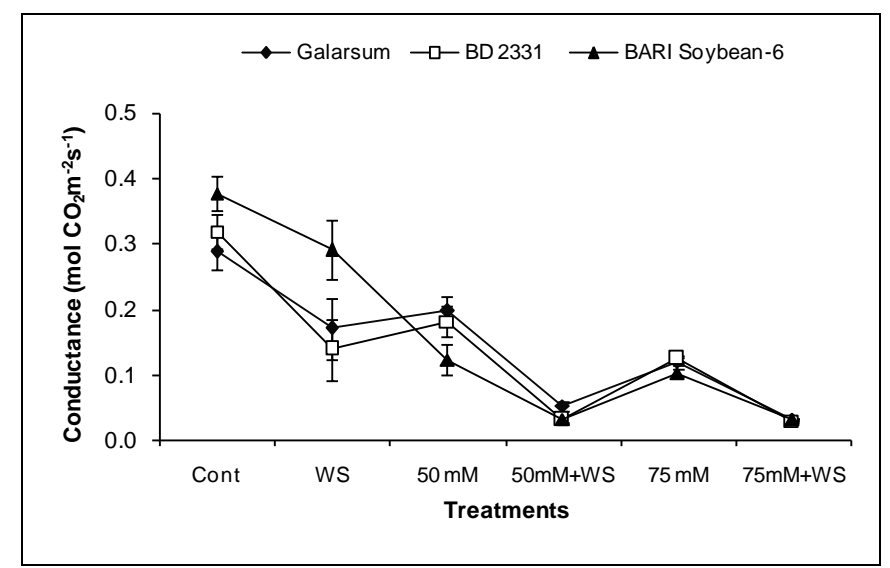

Fig. 2. Total conductance to $\mathrm{CO}_{2}$ as affected by salinity and water stress treatment. Bar represents mean \pm S.E. of the genotypes at the same level of treatment.

Here Cont $=$ Control, WS $=$ Water stress and $\mathrm{mM}=\mathrm{NaCl}$ concentration in $\mathrm{mM}$.

Photosynthetic rate: Photosynthetic rate $(\mathrm{Pn})$ of soybean genotypes significantly declined when plants were exposed to water stress, salt stress and, combined salt + water stress conditions (Fig. 3). Under only water stress condition, BARI Soybean-6 depicted significantly the highest photosynthetic rate $(35.44 \mu \mathrm{mol}$ $\left.\mathrm{CO}_{2} \mathrm{~m}^{-2} \mathrm{~s}^{-1}\right)$, while it drastically reduced in Galarsum $\left(25.24 \mu \mathrm{mol} \mathrm{CO}_{2} \mathrm{~m}^{-2} \mathrm{~s}^{-1}\right)$ and BD $2331\left(21.34 \mu \mathrm{mol} \mathrm{CO}_{2} \mathrm{~m}^{-2} \mathrm{~s}^{-1}\right)$ genotypes. As compared to only the salt water stress and, the combined salt + water stress conditions, Pn rate reduced lesser extent in the salt stress condition. However, the reduction was higher at higher salt stress both in only salt stress and, the combined salt + water stress conditions due to more restriction of water uptake by the roots. The results are in agreement with that of Netondo et al. (2004) who reported that photosynthetic activity decreased when plants were grown under saline conditions. However, significantly the highest photosynthetic rates of 34.49 and $29.47 \mu \mathrm{mol} \mathrm{CO}_{2} \mathrm{~m}^{-2} \mathrm{~s}^{-1}$ were recorded in Galarsum at 50 and $75 \mathrm{mM} \mathrm{NaCl}$ salt stress, respectively. BD 2331 had identical rate at the same treatments. The lowest photosynthetic rate of 
29.70 and $27.30 \mu \mathrm{mol} \mathrm{CO} \mathrm{Cm}^{-2} \mathrm{~s}^{-1}$ were recorded in BARI Soybean- 6 at 50 and 75 $\mathrm{mM} \mathrm{NaCl}$ salt stress, respectively. Under $50 \mathrm{mM} \mathrm{NaCl}+$ water stress condition, Galarsum $\left(23.62 \mu \mathrm{mol} \mathrm{CO}_{2} \mathrm{~m}^{-2} \mathrm{~s}^{-1}\right)$ showed significantly the highest $\mathrm{Pn}$ rate followed by BARI Soybean-6 $\left(21.55 \mu \mathrm{mol} \mathrm{CO} \mathrm{Cm}^{-2} \mathrm{~s}^{-1}\right)$. BD $2331(20.76 \mu \mathrm{mol}$ $\left.\mathrm{CO}_{2} \mathrm{~m}^{-2} \mathrm{~s}^{-1}\right)$ showed the lowest rate. Galarsum $\left(20.45 \mu \mathrm{mol} \mathrm{CO} \mathrm{m}^{-2} \mathrm{~s}^{-1}\right)$ also showed significantly the highest $\mathrm{Pn}$ rate under $75 \mathrm{mM} \mathrm{NaCl}+$ water stress condition. BD 2331 showed the least rate $\left(20.36 \mu \mathrm{mol} \mathrm{CO} \mathrm{Cm}^{-2} \mathrm{~s}^{-1}\right)$, which was identical with the Pn rate of BARI Soybean-6 $\left(20.38 \mu \mathrm{mol} \mathrm{CO} \mathrm{Cm}^{-2} \mathrm{~s}^{-1}\right)$ in the same treatment. The rate of photosynthetic $\mathrm{CO}_{2}$ assimilation is generally reduced by salinity and drought. This reduction is partly due to a reduced stomatal conductance and consequent restriction of the availability of $\mathrm{CO}_{2}$ for carboxylation (Brugnoli and Lauteri, 1991). Wang et al. (2011) reported that photosynthetic rate decreased under salt and water severity in tamarisk seedlings. Eisa et al. (2012) also reported that the net photosynthesis rates were greatly decreased by high salinity and salt-induced photosynthesis inhibition was accompanied with a decrease in transpiration rates but also with improved water use efficiency.

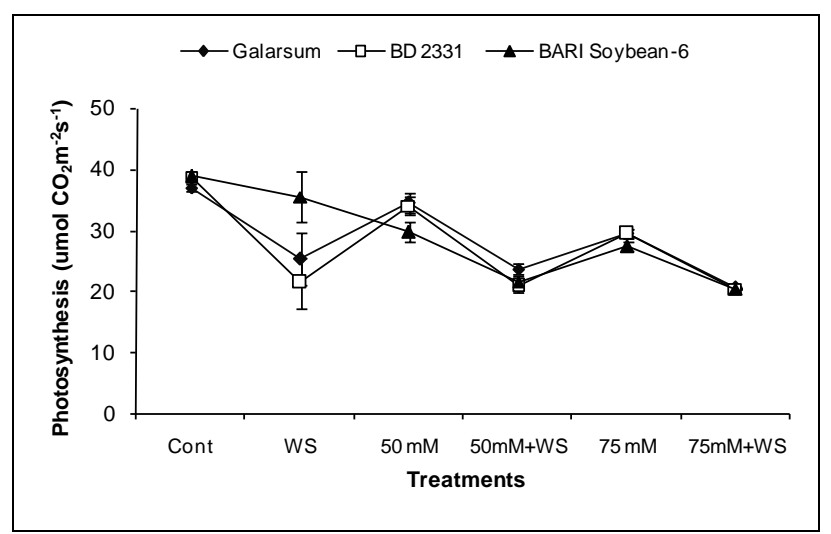

Fig. 3. Leaf photosynthesis as affected by salinity and water stress treatment. Bar represents mean \pm S.E. of the genotype at the same level of treatment.

Here, Cont $=$ Control, $\mathrm{WS}=$ Water stress and $\mathrm{mM}=\mathrm{NaCl}$ concentration in $\mathrm{mM}$.

Transpiration rate: Water stress, salt stress and, combined salt + water stress led to a remarkable reduction in transpiration rate (E) of soybean genotypes as compared to control (Fig. 4). The reduction in water loss through transpiration was mainly due to the reduction of stomatal conductance to $\mathrm{H}_{2} \mathrm{O}$ under salinity and water stress conditions. Genotypes varied in transpiration rates under different stresses. Under only water stress, condition BARI Soybean-6 transpired significantly the highest $\left(11.96 \mathrm{mmol} \mathrm{H}_{2} \mathrm{O} \mathrm{m}^{-2} \mathrm{~s}^{-1}\right)$ compared to others. Galarsum transpired the lowest $\left(4.01 \mathrm{mmol} \mathrm{H}_{2} \mathrm{O} \mathrm{m}^{-2} \mathrm{~s}^{-1}\right)$, which was identical with $\mathrm{BD} 2331$ (4.07 $\mathrm{mmol} \mathrm{H}_{2} \mathrm{O} \mathrm{m}^{-2} \mathrm{~s}^{-1}$ ). Transpiration rate reduced to lesser extent in the salt stress condition than the combined salt + water stress condition. However, at lower level of salt stress $(50 \mathrm{mM} \mathrm{NaCl})$ treatment, significantly the highest 
transpiration rate $\left(7.58 \mathrm{mmol} \mathrm{H}_{2} \mathrm{O} \mathrm{m}^{-2} \mathrm{~s}^{-1}\right)$ was recorded in $\mathrm{BD} 2331$, which was identical (7.38 mmol $\left.\mathrm{H}_{2} \mathrm{O} \mathrm{m}^{-2} \mathrm{~s}^{-1}\right)$ with the rate of Galarsum. BARI Soybean-6 had the lowest rate $\left(6.69 \mathrm{mmol} \mathrm{H}_{2} \mathrm{O} \mathrm{m}^{-2} \mathrm{~s}^{-1}\right)$. At higher level of salt stress $(75 \mathrm{mM}$ $\mathrm{NaCl})$, significantly the highest transpiration $\left(6.66 \mathrm{mmol}_{2} \mathrm{O} \mathrm{m} \mathrm{m}^{-2} \mathrm{~s}^{-1}\right)$ was recorded in BARI Soybean-6 which was identical with the rate of BD 2331 (6.42 mmol $\left.\mathrm{H}_{2} \mathrm{O} \mathrm{m} \mathrm{m}^{-2} \mathrm{~s}^{-1}\right)$. Galarsum showed significantly the least transpiration rate (6.06 mmol $\left.\mathrm{H}_{2} \mathrm{O} \mathrm{m}^{-2} \mathrm{~s}^{-1}\right)$. In the combined salt + water stress conditions the transpiration rate was higher in BARI Soybean- 6 than other genotypes. At the $50 \mathrm{mM} \mathrm{NaCl}+$ with water stress, the highest transpiration rate $\left(2.22 \mathrm{mmol} \mathrm{H}_{2} \mathrm{O}\right.$ $\left.\mathrm{m}^{-2} \mathrm{~s}^{-1}\right)$ was recorded in BARI Soybean-6, which was identical with the rate (2.73 mmol $\mathrm{H}_{2} \mathrm{O} \mathrm{m}^{-2} \mathrm{~s}^{-1}$ ) of Galarsum. On the contrary, BD 2331 showed the least rate $\left(2.55 \mathrm{mmol} \mathrm{H}_{2} \mathrm{O} \mathrm{m}^{-2} \mathrm{~s}^{-1}\right)$. At higher level of salinity $(75 \mathrm{mM} \mathrm{NaCl})+$ water stress treatment, BARI Soybean-6 showed the highest transpiration rate $(2.22 \mathrm{mmol}$ $\left.\mathrm{H}_{2} \mathrm{O} \mathrm{m}^{-2} \mathrm{~s}^{-1}\right)$, which was identical to that of BD 2331(1.80 mmol $\mathrm{H}_{2} \mathrm{O} \mathrm{m} \mathrm{s}^{-2} \mathrm{~s}^{-1}$. At this condition Galarsum showed the lowest transpiration rate $\left(1.45 \mathrm{mmol} \mathrm{H}_{2} \mathrm{O} \mathrm{m}^{-}\right.$ $\left.{ }^{2} \mathrm{~S}^{-1}\right)$. The results are in agreement with the findings of Wang et al. (2011) in tamarisk (Tamarix chinensis Lour.) seedlings. Eisa et al. (2012) reported that the transpiration rates were decreased by high salinity in quinoa. Plants subjected to water and salinity stress had lower stomatal conductance resulted in lower rate of transpiration. Water stress and salinity cause stomatal closure which reduced transpiration rate as reported by Halim et al. (1990).

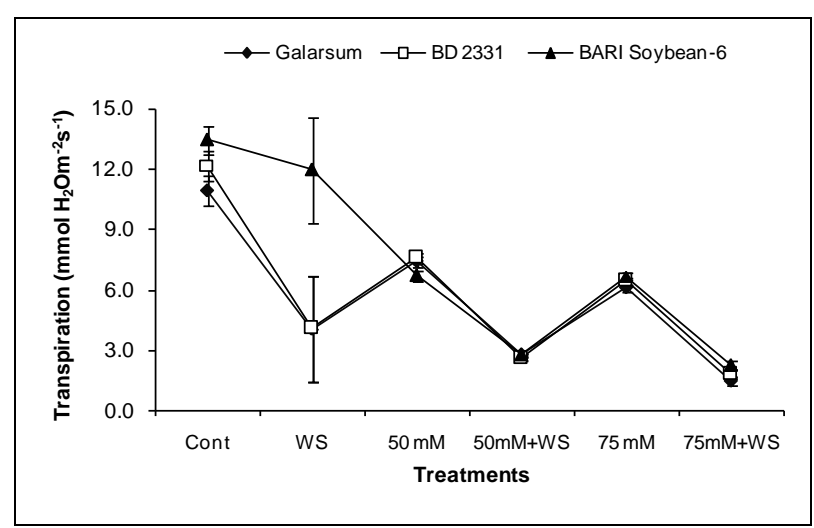

Fig. 4. Leaf transpiration as affected by salinity and water stress treatment. Bar represents mean \pm S.E. of the genotype at the same level of treatment.

Here , Cont $=$ Control, $\mathrm{WS}=$ Water stress and $\mathrm{mM}=\mathrm{NaCl}$ concentration in $\mathrm{mM}$.

Photosynthetic water use efficiency: Water stress, salt stress and, combined salt + water stress led to a strong reduction in soybean plants transpiration rate $(\mathrm{E})$, which reached minimum at higher level of salinity irrespective of water stress and non-water stress conditions (Fig. 5). This led to significantly increase in photosynthetic water use efficiency (PWUE) under different stresses as compared to control. PWUE of soybean genotypes varied under different stresses. Under only water stress condition the highest PWUE (6.35) was 
recorded in Galarsum, which was identical with PWUE (5.30) of BD 2331, though the lowest (2.97) was obtained in BARI Soybean-6.

Under salt stress conditions, PWUE was maximum (4.67 and 4.86 in $50 \mathrm{mM}$ and $75 \mathrm{mM} \mathrm{NaCl}$, respectively) in Galarsum and minimum (4.44 and 4.10 in $50 \mathrm{mM}$ and $75 \mathrm{mM} \mathrm{NaCl}$, respectively) in BARI Soybean-6. At lower level of salinity combined with water stress condition, PWUE was the highest (8.79) in Galarsum, which was identical with the efficiency (8.28) of BD 2331. BARI Soybean-6 showed the lowest efficiency (7.78). At higher level of salinity + water stress conditions, significantly the highest PWUE (14.20) was obtained by Galarsum, which was identical with the efficiency (11.36) of BD 2331 and the lowest (9.19) in BARI Soybean-6. Plants under salt and water deficit conditions usually minimize transpirational water loss and maximize photosynthesis and show higher water-use efficiency (Xu et al., 1994). This is a kind of adaptation mechanism that allows plants to survive water deficit conditions. Salt-induced increase in water use efficiency in Chenopodium was also reported by Eisa et al. (2012).

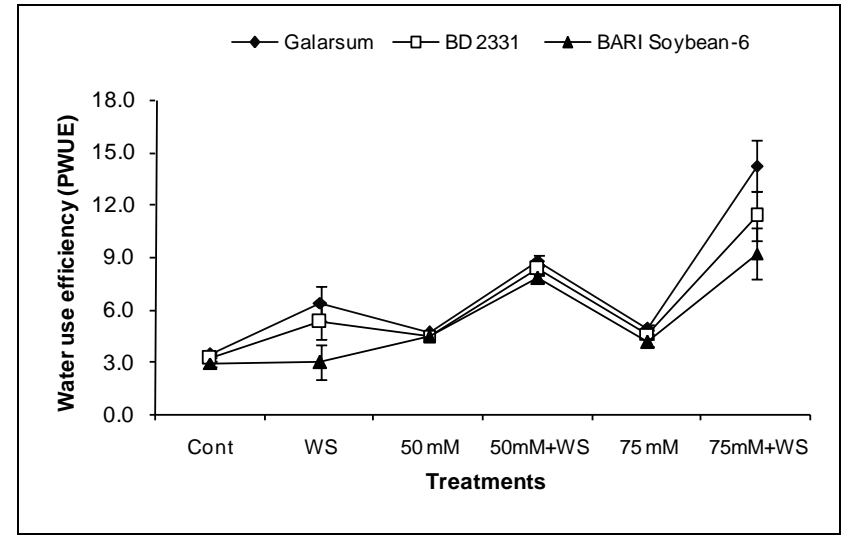

Fig. 5. Photosynthetic water use efficiency $(\mathrm{Pn} / \mathrm{E})$ as affected by salinity and water stress treatment. Bar represents mean \pm S.E. of the genotype at the same level of treatment.

Here, Cont $=$ Control, $\mathrm{WS}=$ Water stress and $\mathrm{mM}=\mathrm{NaCl}$ concentration in $\mathrm{mM}$.

Shoot dry weight: Salinity and water stress significantly affected the shoot dry weight of soybean genotypes measured at 63 days after emergence (Table 1). The lowest shoot dry weight $(3.38 \mathrm{~g})$ was produced by BARI Soybean- 6 at $75 \mathrm{mM}$ $\mathrm{NaCl}$ salt + water stress condition which was identical with the dry matter (3.51 g) of BD 2331 and Galarsum $(3.54 \mathrm{~g})$ at the same treatment. The shoot dry weights were decreased to $24.58,23.00$ and $21.57 \%$ of the control in Galarsum, BD 2331 and BARI Soybean-6, respectively. Shoot dry weight significantly affected in the combined salt + water stress condition as compared to only salt stress in both the salinity levels $(50$ and $75 \mathrm{mM} \mathrm{NaCl})$. It was drastically reduced with the increasing salinity levels along with water stress. However, all the 
genotypes produced identical shoot dry weight at the same level of treatment. At the $75 \mathrm{mM} \mathrm{NaCl}$ salt stress condition BD 2331 produced the lowest shoot dry weight $(5.68 \mathrm{~g})$ followed by BARI Soybean-6 (6.41 g) and Galarsum (6.94 g). Shoot dry weight of soybean genotypes was significantly affected by water stress as compared to control. The lowest shoot dry weights of $4.63 \mathrm{~g}, 5.36 \mathrm{~g}$ and $5.37 \mathrm{~g}$ were recorded in BD 2331, Galarsum and BARI Soybean-6, respectively under water stress conditions. Application of salt water increased the soil salinity and thus decreased the soil water potential though did not decrease water flow to the roots. Root cortical cells can osmotically adjust to some extent allowing water to readily move into the root. Therefore, shoot dry weight of soybean was affected more under salt + water stress conditions than only in salt or water stress conditions. When the soil dries under water stress conditions the soil matric potential is decreased, therefore increased the resistance of water flow to the roots in a non-linear fashion (Homaee et al., 2002). The findings was also an agreement with the findings of Meiri (1984) that the matric potential preferentially affected the shoot growth of bean more than that did the osmotic potential. Wang et al (2011) also reported that shoot biomass decreased significantly in tamarisk seedlings due to water severity under

Table 1. Shoot dry weight of soybean genotypes (g/plant) as affected by salinity and water stress at 63 days after emergence

\begin{tabular}{lcccc}
\hline \multirow{2}{*}{ Treatment } & \multicolumn{3}{|c}{ Genotypes } \\
\cline { 2 - 4 } & Galarsum & BD 2331 & BARI Soybean-6 \\
\hline Control & $14.39 \pm 1.54 \mathrm{a}$ & $15.26 \pm 2.00 \mathrm{a}$ & $15.67 \pm 2.22 \mathrm{a}$ \\
& $(100)$ & $(100)$ & $(100)$ \\
Water stress (WS) & $5.36 \pm 0.98 \mathrm{cde}$ & $4.63 \pm 0.65 \mathrm{de}$ & $5.37 \pm 0.51 \mathrm{cde}$ \\
& $(37.25)$ & $(30.34)$ & $(34.25)$ \\
$50 \mathrm{mM} \mathrm{NaCl}$ & $9.56 \pm 0.88 \mathrm{~b}$ & $8.73 \pm 1.16 \mathrm{bc}$ & $8.36 \pm 1.42 \mathrm{bc}$ \\
& $(66.44)$ & $(57.21)$ & $(53.35)$ \\
$50 \mathrm{mM} \mathrm{NaCl}+\mathrm{WS}$ & $4.82 \pm 0.71 \mathrm{de}$ & $4.21 \pm 1.04 \mathrm{de}$ & $4.26 \pm 0.19 \mathrm{de}$ \\
& $(33.47)$ & $(27.57)$ & $(27.21)$ \\
$75 \mathrm{mM} \mathrm{NaCl}$ & $6.94 \pm 1.24 \mathrm{bcd}$ & $5.68 \pm 0.82 \mathrm{cde}$ & $6.41 \pm 0.17 \mathrm{bcde}$ \\
& $(48.25)$ & $(37.24)$ & $(40.88)$ \\
$75 \mathrm{mM} \mathrm{NaCl}+\mathrm{WS}$ & $3.54 \pm 0.43 \mathrm{e}$ & $3.51 \pm 0.37 \mathrm{e}$ & $3.38 \pm 0.81 \mathrm{e}$ \\
& $(24.58)$ & $(23.00)$ & $(21.57)$ \\
\hline $\mathrm{HSD}(0.05)$ & \multicolumn{4}{c}{3.38} \\
Std Error & \multicolumn{4}{c}{0.90} \\
$\mathrm{CV}(\%)$ & & 15.27 & \\
\hline
\end{tabular}

Different letters indicate a significant difference at $\mathrm{P}=0.05$. Lettering was made for observing the variation in genotype $\mathrm{x}$ environmental response.

Data in parenthesis indicate percentage of shoot dry weight to control.

salt and water stress condition. The reduction in shoot dry weight due to salinity was reported by Karim et al. (1993) in triticale, Khan et al. (1997) in rice, Aziz et al. (2005) in mungbean, Chookhampaeng (2011) in pepper plant and Mannan et al. (2013a) in soybean. 
Sodium accumulation: The accumulation of $\mathrm{Na}^{+}$in the leaves of soybean genotypes was significantly affected by salinity and water stress treatments (Table 2). The highest accumulation $(0.171 \%)$ was obtained from BARI soybean- 6 at $75 \mathrm{mM} \mathrm{NaCl}$ salt stress, which was followed by BD $2331(0.149 \%)$. The genotype Galarsum accumulated significantly lower $(0.138 \%)$ than others at the same treatment. The lowest accumulation (0.061\%) was obtained from Galarsum under only water stress treatment, which was identical with BD 2331 $(0.066 \%)$ in the same treatment and also from Galarsum $(0.066 \%)$ under control. The results revealed that the accumulation of $\mathrm{Na}^{+}$was higher in the salt stress conditions at both the salinity levels $(50$ and $75 \mathrm{mM} \mathrm{NaCl})$ than the combined salt + water stress conditions, and the accumulation increased with the rise of salinity level. However, at $75 \mathrm{mM} \mathrm{NaCl}+$ water stress treatment, all the three genotypes accumulated identical amount of $\mathrm{Na}^{+}$. Among the genotypes, BARI Soybean- 6 accumulated maximum $(0.116 \%)$ followed by BD $2331(0.113 \%)$ and the Galarsum accumulated minimum $(0.110 \%)$ at the same treatment. The higher accumulation of $\mathrm{Na}^{+}$in leaves under salinity and water stress might be due to higher transpiration rate. Differences in $\mathrm{Na}^{+}$accumulation in soybean genotypes revealed that the genotype Galarsum, which accumulated lower $\mathrm{Na}^{+}$was more tolerant than that of BD 2331 and BARI Soybean-6. The mechanisms of plant responses to salt and water stress have much in common, because salinity leads to many metabolic changes that are identical to those caused by water stress. The results of the study are in agreement with the earlier reports that the tolerant genotypes accumulate less amounts of $\mathrm{Na}$ than susceptible ones (Karim et al., 1992; Khan et al., 1997; Ahmadi et al., 2009; Mannan et al., 2013). The excess amount of $\mathrm{Na}^{+}$creates a toxic effect on plant metabolic processes and therefore, the susceptible cultivars having high amounts of $\mathrm{Na}^{+}$suffer more from the effect than the tolerant cultivars (Blum, 1988; Karim et al., 1992). Kao et al. (2006) also reported that differences among soybean species in leaf accumulation of $\mathrm{Na}^{+}$ might be responsible for the differential sensitivity to $\mathrm{NaCl}$ treatments.

Table 2. Sodium (Na) uptake in leaf tissue (\%) of soybean genotypes after 6 weeks of imposition of the stress treatments

\begin{tabular}{l|c|c|c}
\hline \multirow{2}{*}{ Treatment } & \multicolumn{3}{|c}{ Genotypes } \\
\cline { 2 - 4 } & Galarsum & BD 2331 & BARI Soybean-6 \\
\hline Control & $0.066 \pm 0.001 \mathrm{ij}$ & $0.072 \pm 0.004 \mathrm{hi}$ & $0.077 \pm 0.005 \mathrm{~h}$ \\
Water stress (WS) & $0.061 \pm 0.003 \mathrm{j}$ & $0.066 \pm 0.001 \mathrm{ij}$ & $0.072 \pm 0.0041 \mathrm{hi}$ \\
$50 \mathrm{mM} \mathrm{NaCl}$ & $0.127 \pm 0.002 \mathrm{~d}$ & $0.127 \pm 0.002 \mathrm{~d}$ & $0.143 \pm 0.003 \mathrm{bc}$ \\
$50 \mathrm{mM} \mathrm{NaCl}+\mathrm{WS}$ & $0.094 \pm 0.003 \mathrm{~g}$ & $0.099 \pm 0.003 \mathrm{~g}$ & $0.101 \pm 0.003 \mathrm{fg}$ \\
$75 \mathrm{mM} \mathrm{NaCl}$ & $0.138 \pm 0.003 \mathrm{c}$ & $0.149 \pm 0.003 \mathrm{~b}$ & $0.171 \pm 0.007 \mathrm{a}$ \\
$75 \mathrm{mM} \mathrm{NaCl}+\mathrm{WS}$ & $0.110 \pm 0.003 \mathrm{ef}$ & $0.113 \pm 0.004 \mathrm{e}$ & $0.116 \pm 0.004 \mathrm{e}$ \\
\hline HSD $(0.05)$ & & 0.01 & \\
Std Error & & 0.003 & \\
CV $(\%)$ & & 3.15 & \\
\hline
\end{tabular}

Different letters indicate a significant difference at $\mathrm{P}=0.05$. Lettering was made for observing the variation in genotype $\mathrm{x}$ environmental response. 
Potassium accumulation: The accumulation of $\mathrm{K}^{+}$in the leaves of soybean genotypes was significantly affected by salinity and water stress treatments (Table 3). The highest accumulation (1.25\%) was obtained in Galarsum at 50 $\mathrm{mM} \mathrm{NaCl}$ salt combined with water stress, which was identical with the same genotype at $50 \mathrm{mM} \mathrm{NaCl}(1.24 \%)$, and also BD $2331(1.22 \%)$ and BARI Soybean-6 (1.24\%) at only water stress. The accumulation of $\mathrm{K}^{+}$was significantly decreased at $75 \mathrm{mM} \mathrm{NaCl}$ salt stress and also combined water stress treatment irrespective of variety. However, the accumulation was to some extent increased in the combined salt + water stress conditions than only the salt stress conditions. The lowest $(1.12 \%)$ amount of $\mathrm{K}^{+}$accumulation was obtained from BARI Soybean-6 at $75 \mathrm{mM} \mathrm{NaCl}$ salt stress, which was identical with the same genotype at $75 \mathrm{mM} \mathrm{NaCl}$ salt + water stress (1.13\%) and BD $2331(1.16 \%)$ at 75 $\mathrm{mM} \mathrm{NaCl}$ salt stress. At $75 \mathrm{mM} \mathrm{NaCl}+$ water stress treatment, genotype Galarsum accumulated the maximum (1.19\%) amount of $\mathrm{K}^{+}$, which was identical with the same genotype at $75 \mathrm{mM} \mathrm{NaCl}$ salt stress (1.18\%) and with $\mathrm{BD} 2331$ both at salt and water stress treatments. Under water and salt stress conditions $\mathrm{K}^{+}$ plays an important role in osmoregulation and the tolerant genotype accumulates higher amounts than the susceptible ones (Blum, 1988; Qadar, 1988). Maintenance of high cytoplasmic levels of $\mathrm{K}^{+}$is essential for survival of plants in saline habitats (Chow et al., 1990). Here, the soybean genotype Galarsum accumulated higher amount of $\mathrm{K}^{+}$in leaves than others under salt and water stress conditions. It could be due to high potentiality of the genotype.

Table 3. Potassium (K) uptake in leaf tissue (\%) of soybean genotypes after 6 weeks of imposition of the stress treatments

\begin{tabular}{l|c|c|c}
\hline \multirow{2}{*}{ Treatment } & \multicolumn{3}{|c}{ Genotypes } \\
\cline { 2 - 4 } & Galarsum & BD 2331 & BARI Soybean-6 \\
\hline Control & $1.166 \pm 0.006 \mathrm{e}-\mathrm{g}$ & $1.176 \pm 0.007 \mathrm{~d}-\mathrm{f}$ & $1.155 \pm 0.013 \mathrm{f}-\mathrm{h}$ \\
Water stress (WS) & $1.197 \pm 0.009 \mathrm{c}-\mathrm{e}$ & $1.218 \pm 0.005 \mathrm{a}-\mathrm{c}$ & $1.239 \pm 0.006 \mathrm{ab}$ \\
$50 \mathrm{mM} \mathrm{NaCl}$ & $1.239 \pm 0.006 \mathrm{ab}$ & $1.197 \pm 0.009 \mathrm{c}-\mathrm{e}$ & $1.187 \pm 0.005 \mathrm{c}-\mathrm{f}$ \\
$50 \mathrm{mM} \mathrm{NaCl}+\mathrm{WS}$ & $1.250 \pm 0.026 \mathrm{a}$ & $1.208 \pm 0.033 \mathrm{~b}-\mathrm{d}$ & $1.197 \pm 0.009 \mathrm{c}-\mathrm{e}$ \\
$75 \mathrm{mM} \mathrm{NaCl}$ & $1.176 \pm 0.007 \mathrm{~d}-\mathrm{f}$ & $1.155 \pm 0.013 \mathrm{f}-\mathrm{h}$ & $1.124 \pm 0.006 \mathrm{~h}$ \\
$75 \mathrm{mM} \mathrm{NaCl}+\mathrm{WS}$ & $1.187 \pm 0.005 \mathrm{~cd}-\mathrm{f}$ & $1.166 \pm 0.007 \mathrm{e}-\mathrm{g}$ & $1.134 \pm 0.006 \mathrm{gh}$ \\
\hline HSD $(0.05)$ & & 0.039 & \\
Std Error & & 0.01 & \\
CV $(\%)$ & & 1.07 & \\
\hline
\end{tabular}

Different letters indicate a significant difference at $\mathrm{P}=0.05$. Lettering was made for observing the variation in genotype $\mathrm{x}$ environmental response.

Ratio of Potassium and Sodium: The ratio of $\mathrm{K}^{+}$and $\mathrm{Na}^{+}$was decreased under salt and water stress treatments and decreased sharply at the higher salt concentration (Fig. 6). Under only water stress treatment, significantly the highest ratio (17.73) of potassium and sodium was obtained from Galarsum, 
which was identical with the ratio (16.45) in BD 2331, while the lowest (15.00) in BARI Soybean-6. Under $75 \mathrm{mM} \mathrm{NaCl}$ salt stress treatment, the highest $\mathrm{K}^{+}$: $\mathrm{Na}^{+}$ratio (8.55) was obtained from Galarsum, which was identical with the ratio (7.78) obtained from BD 2331 and the lowest (6.59) from BARI Soybean-6. The ratio was to some extent increased in the combined salt and water stress conditions than only in the salt stress treatments. However, at $75 \mathrm{mM} \mathrm{NaCl}$ salt + water stress treatment the highest ratio (10.79) was also obtained from Galarsum, and the lowest (9.82) from BARI Soybean-6, which was identical with the ratio (10.31) obtained from BD 2331. The results are in agreement with the findings that tolerant genotypes maintain a higher $\mathrm{K}^{+} / \mathrm{Na}^{+}$ratio than susceptible ones (Nair and Khulbe, 1990; Mannan et al., 2013b). A greater degree of salt tolerance in plants was found to be associated with a more efficient system for selective uptake of $\mathrm{K}^{+}$over $\mathrm{Na}^{+}$(Neill et al., 2002). The selective uptake of $\mathrm{K}^{+}$in contrast to $\mathrm{Na}^{+}$was considered as one of the important physiological mechanisms contributing to salt tolerance in many plant species (Poustini and Siosemardeh, 2004).

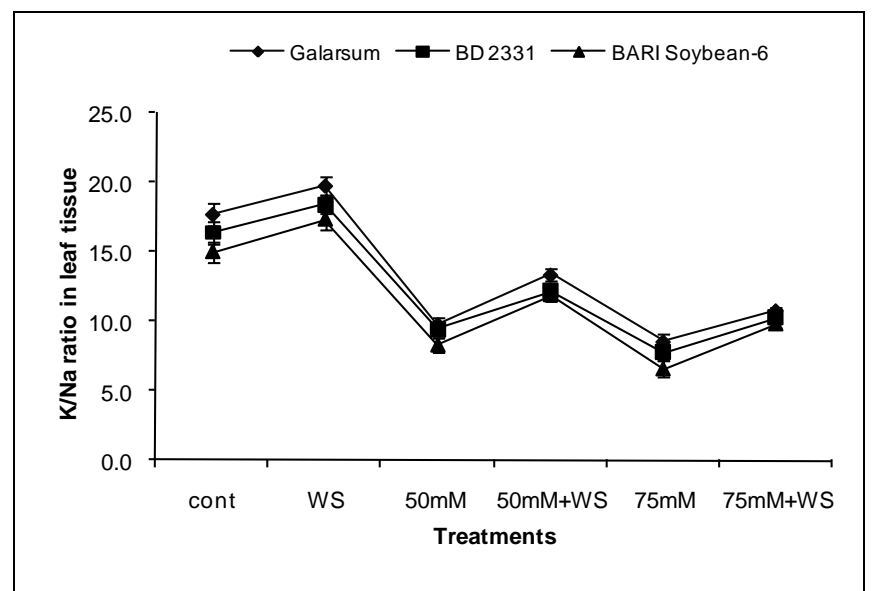

Fig. 6. K/Na ratio in leaf tissue of soybean genotypes after 6 weeks of beginning of the stress treatments. Bar represents mean \pm S.E. of the genotype at the same level of treatment.

Here, Cont $=$ Control, $\mathrm{WS}=$ Water stress and $\mathrm{mM}=\mathrm{NaCl}$ concentration

\section{Conclusion}

Salinity and water stress had severe adverse effect on stomatal conductance, photosynthesis and transpiration rate of soybean genotypes. The genotype Galarsum minimized transpiritional water loss and maximized photosynthesis as compared to BD 2331 and BARI Soybean-6 under salt and water stress environments. Combined salt + water stress caused greater inhibition of shoot growth than either only salt or water stress in soybean. Galarsum accumulated higher amount of $\mathrm{K}^{+}$and lower amount of $\mathrm{Na}^{+}$in leaves under salt and water 
stress. The results indicated that the genotype Galarsum is more capable in tolerating high levels of salt under water stress condition than BD 2331 and BARI Soybean-6.

\section{References}

Ahmadi, A., Y. Emam and M. Pessarakli. 2009. Response of various cultivars of wheat and maize to salinity stress. J. Food Agri. Environ. 7: $123-128$.

Aziz, M.A., M.A. Karim, M.A. Hamid, Q.A. Khalique and M. Hossain. 2005. Salt tolerance in mungbean: Growth and yield response of some selected mungbean genotypes to $\mathrm{NaCl}$ salinity. Bangladesh J. Agric. Res. 30: 529-535.

Blum, A. 1988. Salinity resistance. In: Plant Breeding for Stress Environments. CRC Press, Florida. Pp. 163-179.

Brugnoli E., and M. Lauteri. 1991. Effects of salinity on stomatal conductance, photosynthetic capacity, and carbon isotope discrimination of salt - resistant (Gossypium hirsutum L.) and salt-sensitive (Phaseolus vulgaris L) $\mathrm{C}_{3}$ nonhalophyties. Plant Physiol., 95: 628-635.

Chookhampaeng, S. 2011. The effect of salt stress on growth, chlorophyll content proline content and antioxidative enzymes of Pepper (Capsicum Аnnuит L.) seedling. Euro. J. Sci. Res. Vol.49 (1), Pp.103-109.

Chow, W. S., M. C. Ball, and J. S. Anderson 1990. Growth and photosynthetic responses of spinach to salinity. Implication of $\mathrm{K}^{+}$nutrition for salt tolerance. Aust. J. Plant Physiol. 17: 563-578.

Dadkhah A.R. 2010. Effect of long term salt stress on gas exchange and leaf carbohydrate contents in two sugar beet (Beta vulgaris L.) cultivars. Res. J. Biol. Sci., 5(8): 512-516.

Eisa, S., S. Hussin, N. Geissler and H.W. Koyro. 2012. Effect of $\mathrm{NaCl}$ salinity on water relations, photosynthesis and chemical composition of Quinoa (Chenopodium quinoa Willd.) as a potential cash crop halophyte. Aust. J. Crop. Sci. 6(2):357-368.

Greenway, H. and R. Munns. 1980. Mechanisms of salt tolerance in nonhalophytes. Ann. Rev. Plant Physiol. 31: 149-190.

Halim, R.A., D.R. Buxton, M.J. Hattendorf and R.E. Carison. 1990. Crop water stress index and forage quality relationships in alfalfa. Agric. J., 82: 906-909.

Homaee, M., R.A. Feddes and C. Dirksen. 2002. A macroscopic water extraction model for nonuniform transient salinity and water stress. Soil Sci. Soc. Am. J., 66: 17641772.

Islam, M.N., and M.S. Rahman. 2011. Performance of soybean varieties in the charland area (AEZ-11). In: Charland Research 2007-2010. Charland publication no. 1. Agronomy Division, BARI, Joydebpur, Gazipur.

Jiang, H., X.H. Wang, Q.Y. Deng, L.P. Yuan and D.Q. Xu. 2002. Comparison of some photosynthetic characters between two hybrid rice combinations differing in yield potential. Photosynthetica. 40: 133-137. 
Kao, W., T.T. Tyng, C.T. Hung and N.S. Chen. 2006. Response of three Glycine species to salt stress. Environ. Exp. Bot. 56: 120-125.

Karim, M.A., M.M. Haque and A. Hamid. 2014. Concern, opportunity and strategic research in crop sector under climate change context in Bangladesh. In: Rising Atmospheric $\mathrm{CO}_{2}$ and Crop Response. A compendium of published works at BSMRAU, Bangladesh. Pp. 1-64.

Karim, M.A., E. Nawata and S. Shigenaga. 1993. Effects of salinity and water stress on growth, yield and physiological characteristics in hexaploid triticale. Japanese Journal of Trop. Agr. 37(1): 46-52.

Karim. M.A., T. Kondo, K. Ueda, H. Higuchi, and E. Nawata. 2012. Effect of $\mathrm{NaCl}$ tratment on Growth and Some Physiological Chararacteristics of a salt-tolerant soybean genotype AGS 313 bred in Bangladesh. Tropical Agriculture and Development. 56: 139-142.

Karim, M.A., N. Utsunomiya, N. and S. Shigenaga. 1992. Effect of sodium chloride on germination and growth of hexaploid triticale at early seedling stage. Japan J. Crop Sci. 61(2): 279-284

Khan, M.S.A., A. Hamid, A.B.M. Salahuddin, A. Quasem and M.A. Karim. 1997. Effect of sodium chloride on growth, photosunthesis and mineral ions accumulation of different types of rice (Oryza sativa L.). J. Agron. Crop Sci. 179: 149-161.

Khan, M.S.A., M.A. Karim and M.M. Haque. 2014. Genotypic differences in growth and ions accumulation in soybean under $\mathrm{NaCl}$ salinity and water stress conditions. Bangladesh Agron. J. 17(1): 47-58.

Kusvuran, S., 2012. Effects of drought and salt stresses on growth, stomatal conductance, leaf water and osmotic potentials of melon genotypes (Cucumis melo L.). African J. Agril. Res. Vol. 7(5): 775-781.

Lee, G., R.N. Carrow and R.R. Duncan. 2004. Photosynthetic responses to salinity stress of halophytic seashore paspalum ecotypes. Plant Sci. 166: 1417-1425.

Mannan, M.A., M.A. Karim, M.M. Haque, Q.A. Khaliq, H. Higuchi and E. Nawata. 2012. Response of soybean to salinity: I. Genotypic variations in salt tolerance at the vegetative stage. Trop. Agr. Develop. Vol. 56(4): 117-122.

Mannan, M.A., M.A. Karim, M.M. Haque, Q.A. Khaliq, H. Higuchi and E. Nawata. 2013a. Response of soybean to salinity: II. Growth and yield of some selected genotypes. Trop. Agr. Develop. Vol. 57(1): 31-40.

Mannan, M.A., M.A. Karim, M.M. Haque, Q.A. Khaliq, H. Higuchi and E. Nawata. 2013b. Response of soybean to salinity: III. Water status and accumulation of mineral ions. Trop. Agr. Develop. Vol. 57(1): 41-48.

Meiri, A. 1984. Plant response to salinity: Experimental methodology and application to the field. p. 284-297. In I. Shainberg and J. Shalhevet (eds.) Soil Salinity Under rrigation. Springer Verlag, New York.

Munns, R., R.A. Hare, R.A. James and G.J. Rebetzke. 2000. Genetic variation for improving the salt resistance of durum wheat. Aust. J. Agric. Res., 51: 69-74. 
Nair, K.P.P., and N.C. Khulbe, 1990. Differential response of wheat and barley genotypes to substrate-induced salinity under north Indian conditions. Expt. Agric. 26: $221-225$.

Neill, S., R. Desikan, and J. Hancock. 2002. Hydrogen peroxide signalling. Curr. Opin. Plant Biol. 5: 388-395.

Netondo, G.W., J.C. Onyango and E. Beck. 2004. Sorghum and salinity. II. Gas exchange and chlorophyll fluorescence of sorghum under salt stress. Crop Sci., 44: 806-811.

Orcutt, M.D. and E.T. Nilsen. 2000. Salinity Stress. In: The Physiology of plants under stress. Pp. 177-234. John Wiley and Sons, Inc. New York.

Poustini, K. and A. Siosemardeh. 2004. Ion distribution in wheat cultivars in response to salinity stress. Field Crops Res. 85: 125- 33.

Purwanto, E. 2003. Photosynthesis activity of soybean (Glycine max L.) under drought stress. Agrosains J. 5(1): 13-18.

Qadar, A. 1988. Potassium status of the rice shoot as an index for salt tolerance. Ind. J. Plant Physiol. 31: 388-393.

Schroeder, J.I., J.M. Ward and W. Gassmann. 1994. Perspectives on the physiology and structure of inward-rectifying $\mathrm{K}+$ channds in higher plants: biophysical implications for $\mathrm{K}^{+}$uptake. Annu Rev Biophys Biomol Struct. 23: 441-471

Tester, M. and R. Davenport. 2003. Na+ resistance and $\mathrm{Na}+$ transport in higher plants. Ann. Bot. 91: 1-25.

Turner N.C., J.E. Begg and M.L. Tonnet 1998. Osmotic adjustment of sorghum and sunflower crops in response to water deficits and its influence on the water potential at which stomta close. Aust. J. Plant Physiol. 5(5): 597-608.

Wang, Wei, R. Wang, Y. Yuan, N. Du and W. Guo. 2011. Effects of salt and water stress on plant biomass and photosynthetic characteristics of Tamarisk (Tamarix chinensis Lour.) seedlings. Afr. J. Biotechnol. Vol. 10(78): 17981-89.

Watad, A.A, M. Reuveni, R.A. Bressan and P.M. Hasegawa.1991. Enhanced net K ${ }^{+}$ uptake capacity of NaC1 adapted cells. Plant Physiol. 95: 1265-1269.

Xu H.L., L. Gauthier and A. Gosselin. 1994. Photosynthetic responses of greenhouse tomato plants to high solution electrical conductivity and low soil water content. J. Hort. Sci. 69:821-832.

Yaklich, R.W., B. Vinyard, M. Camp and S. Douglass. 2002. Analysis of seed protein and oil from soybean northern and southern region uniform tests. Crop Sci. 42: 1504-15.

Zhang, C., H. Chu, G. Chen, D. Shi, M. Zuo, J. Wang, C. Lu, P. Wang and L.Chen. 2007. Photosynthetic and biochemical activities in flag leaves of a newly developed super high yield hybrid rice (Oryza sativa L) and its parents during the reproductive stage. J. Plant Res. 120: 209-217. 
